\title{
Runoff and inter-rill erosion in a Maritime Pine and a Eucalypt plantation following wildfire and terracing in north-central Portugal
}

\author{
Martinho A.S. Martins, Ana I. Machado, Dalila Serpa, Sergio A. Prats, Sílvia R. Faria, \\ María E.T. Varela, Óscar González-Pelayo, J. Jacob Keizer*
}

Centre for Environmental and Marine Studies (CESAM), Department of Environment and Planning, University of Aveiro, Campus Universitário de Santiago, 3810-193 Aveiro, Portugal.

*Corresponding author. Tel.: +351 234 370200. Fax: +351 234 370309. E-mail: jjkeizer@ua.pt

\begin{abstract}
The purpose of this study was to assess how terracing affected overland flow and associated sediment losses, at the micro-plot scale $\left(0.25 \mathrm{~m}^{2}\right)$, in recently burnt stands of the two principal forest types in north-central Portugal, i.e. mono-specific stands of Maritime Pine and Eucalypt. Terracing is an increasingly common practice of slope engineering in the study region but its impacts on runoff and erosion are poorly studied. Non-terraced plots at the Eucalypt and the Pine site revealed similar median runoff coefficients (rc: 20-30\%) as well as comparable median sediment losses (15-25 $\mathrm{g} \mathrm{m}^{-2}$ ) during the first seven months following wildfire. During the ensuing, slightly wetter 18-month period, however, non-terraced plots at the Pine site lost noticeably more sediments (in median, $90 \mathrm{vs.} 18 \mathrm{~g} \mathrm{~m}^{-2}$ ), in spite the runoff response had remained basically the same (median rc: 33 vs. 28\%). By contrast, terraced plots at the same Pine site lost hugely more sediments (in median, $1,200 \mathrm{~g} \mathrm{~m}^{-2}$ ) during this 18-month period. Terraced plots at the Eucalypt site even lost three times more sediments (in median, 3,600 $\mathrm{g} \mathrm{m}^{-2}$ ). Ground cover and resistance to shear stress seemed to be key factors in the observed/inferred impacts of terracing.
\end{abstract}

Keywords: Wildfire; Terracing; Eucalypt; Pine; Overland flow; Erosion.

\section{INTRODUCTION}

In the past three decades, wildfires have become a common phenomenon in Portugal, especially during the summer. Wildfires in Portugal have, on average, affected some 100,000 ha year $^{-1}$ since the 1980s but well over 300,000 ha year $^{-1}$ in exceptional years such as 2003 and 2005 (Pereira et al., 2006). This elevated wildfire incidence can be attributed to climate conditions that are propitious to wildfire as well as to biomass production, in combination with various socio-economic factors (Moreira et al., 2001; Radich and Alves, 2000; Shakesby, 2011). The principal socio-economic factors are the large-scale replacement of native Portuguese forest by commercial plantations of fire-prone tree species (especially Pine and Eucalypt), the decline in traditional practices (grazing and coppicing, reducing the accumulation of flammable materials), and land abandonment. Since the underlying socio-economic causes are of a structural nature and since meteorological conditions propitious to wildfire are expected to increase with climate change, wildfire occurrence in Portugal is not expected to decrease in the foreseeable future (Pereira et al., 2006).

Wildfires can produce striking changes in hydrological and erosion processes in Mediterranean ecosystems, as thoroughly reviewed by Cerdà and Bodí (2007) for Spain and Shakesby (2011) for the Mediterranean Basin. Fire-enhanced runoff and erosion rates are generally attributed to the partial removal of the protective vegetation and litter cover, combined with heating-induced alterations in soil properties controlling runoff generation and soil erodibility, for example soil water repellency and aggregate stability (Cerdà, 1998; Cerdà and Doerr, 2008; Leighton-Boyce et al., 2007; Mataix-Solera et al., 2011). Strong increases in runoff and erosion following wildfire have also been inferred for the two principal forest types in northcentral Portugal, Maritime Pine and Eucalypt plantations (Ferreira et al., 2008; Leighton-Boyce et al., 2007; Malvar et al., 2013; Prats et al., 2012; Shakesby et al., 1993).
Post-fire forestry practices can also strongly influence overland flow and erosion in recently burnt areas. For example, variations in logging activities of Eucalypt plantations in northeastern Spain resulted in erosion rates ranging from less than 1 to more than $40 \mathrm{Mg} \mathrm{ha}^{-1} \mathrm{y}^{-1}$ (Fernandéz et al., 2004). In northcentral Portugal, rip-ploughing in downslope direction led to greater soil losses than wildfire (Shakesby et al., 1994). Ripploughing in downslope direction is now forbidden in the study region but the construction of terraces for reforestation with Eucalypt has become increasingly common, especially also in recently burnt areas (Fig. 1). Although terraces are traditionally viewed as a technique for soil conservation, ploughing for constructing terraces in new citron plantations has been found to produce erosion rates that were exceptionally high for western Mediterranean standards (Cerdà et al., 2009). The present authors have measured high splash erosion rates on recent terraces (Fernandéz-Raga et al., 2010), and have regularly observed small-scale erosion features (pedestals, collapsing terrace sides, rills) and even gully formation on terraced hill slopes in Portugal. Runoff and associated sediment losses, however, are poorly quantified for recently terraced forest plantations (Shakesby, 2011). The overarching aim of the present study was to address this knowledge gap, focusing on overland flow and inter-rill erosion at the micro-plot scale during the initial post-disturbance period as a first step towards assessing the overall impacts of this form of slope engineering, at the slope and watershed scale and over a full plantation cycle. The specific objectives were to assess the hydrological and erosion effects of terracing: (i) directly, by comparing two adjacent slope sections of a single Maritime Pine plantation, of which one was terraced some seven months after a wildfire and the other left undisturbed; (ii) indirectly, by comparing pre- and post-terracing at a nearby Eucalypt plantation. 


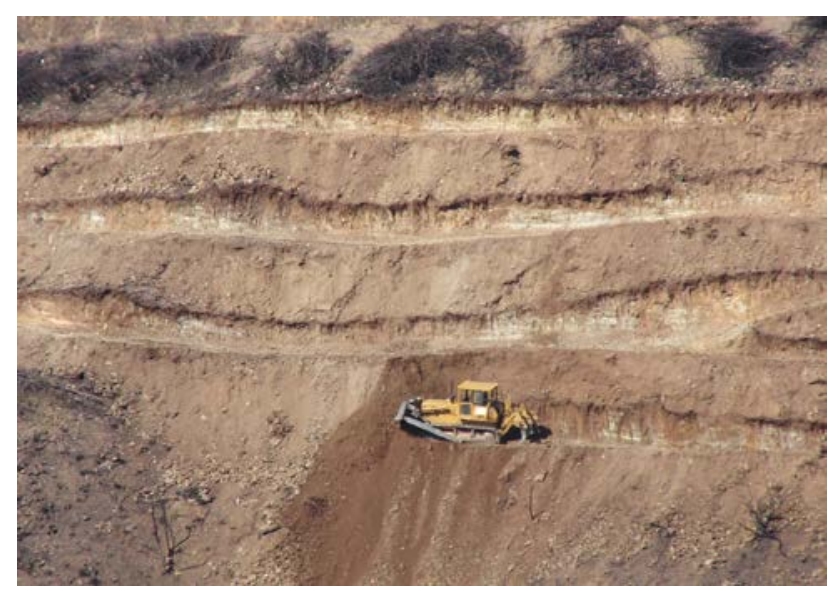

Fig. 1. Illustration of terrace construction, using a bulldozer, on a very steep slope in a recently burnt area in central Portugal, in preparation of new Eucalypt plantation.

\section{MATERIAL AND METHODS Study area}

The study area was located in the Sever do Vouga municipality, north-central Portugal. The area surrounding the Ermida hamlet was affected by a wildfire that occurred between July 26 and 282010 (AFN, 2012). The burnt area comprised approximately 300 ha, which, at the time of the fire, was mainly covered by Eucalypt (Eucalyptus globulus Labill.) plantations but also included some Maritime Pine (Pinus pinaster Ait.) plantations and a stand of Cork Oak (Quercus suber L.).

The climate of the study area can be classified as humid meso-thermal (Csb, according to the Köppen classification), with moderately dry but extended summers (DRA-Centro, 1998). At the nearest weather station $\left(40^{\circ} 51^{\prime} 16^{\prime \prime} \mathrm{N}, 8^{\circ} 22^{\prime} 55^{\prime}\right.$ 'W; SNIRH, 2011), the long-term mean annual temperature was $14.9^{\circ} \mathrm{C}$. At the nearest rainfall station $\left(40^{\circ} 44^{\prime} 39^{\prime} \mathrm{N}, 8^{\circ} 18^{\prime} 05^{\prime} \mathrm{W}\right.$; SNIRH, 2011), annual rainfall was, on average, $1.609 \mathrm{~mm}$ but varied strongly, from 960 to $2.530 \mathrm{~mm}$.

The study area pertains to the Hespheric Massif, one of the region's major physiographic units (Ferreira, 1978). The Hespheric Massif mainly consists of pre-Ordovician schists and greywackes but includes Hercynian granites at several locations. According to the existing soil map $(1: 1,000,000$; Cardoso et al., 1971, 1973), the soils in the study area are predominantly Humic Cambisols.

\section{Study sites}

Two contrasting study sites were selected at less than $500 \mathrm{~m}$ distance within the burnt area: a Eucalypt plantation over granite and a Maritime Pine plantation over schist (Fig. 2). Both study sites corresponded to steep (around $25^{\circ}$ ) but short (40-80 $\mathrm{m})$ slopes, with a SE exposition. By the time of the fire, the Eucalypt plantation was in its second rotation (the trees having been logged once and left to regrow from the stumps) and, thus, some 15-20 year old, whereas the Pine plantation was estimated at 30-40 years old. At both study sites, fire severity sensu Keeley (2009) had apparently been moderate. This was inferred, following Shakesby and Doerr (2006), see also Malvar et al., (2011, 2013), from the scorching rather than consumption of the majority of tree crowns, the total consumption of most of the undergrowth vegetation and the predominantly black color of the ashes. At the bottom of the each of two study slopes, the trail side was cleared at various points for a field description of the soil profiles. In accordance with the WRB (2006), the soils ranged from Humic Leptosols to Humic Cambisols at the Eucalypt site, and from Lithic Leptosols to Humic Leptosols at the Pine site. Soil texture was determined in the field as being slightly coarser at the Eucalypt site (sandy loam) than at the Pine site (sandy clay loam).

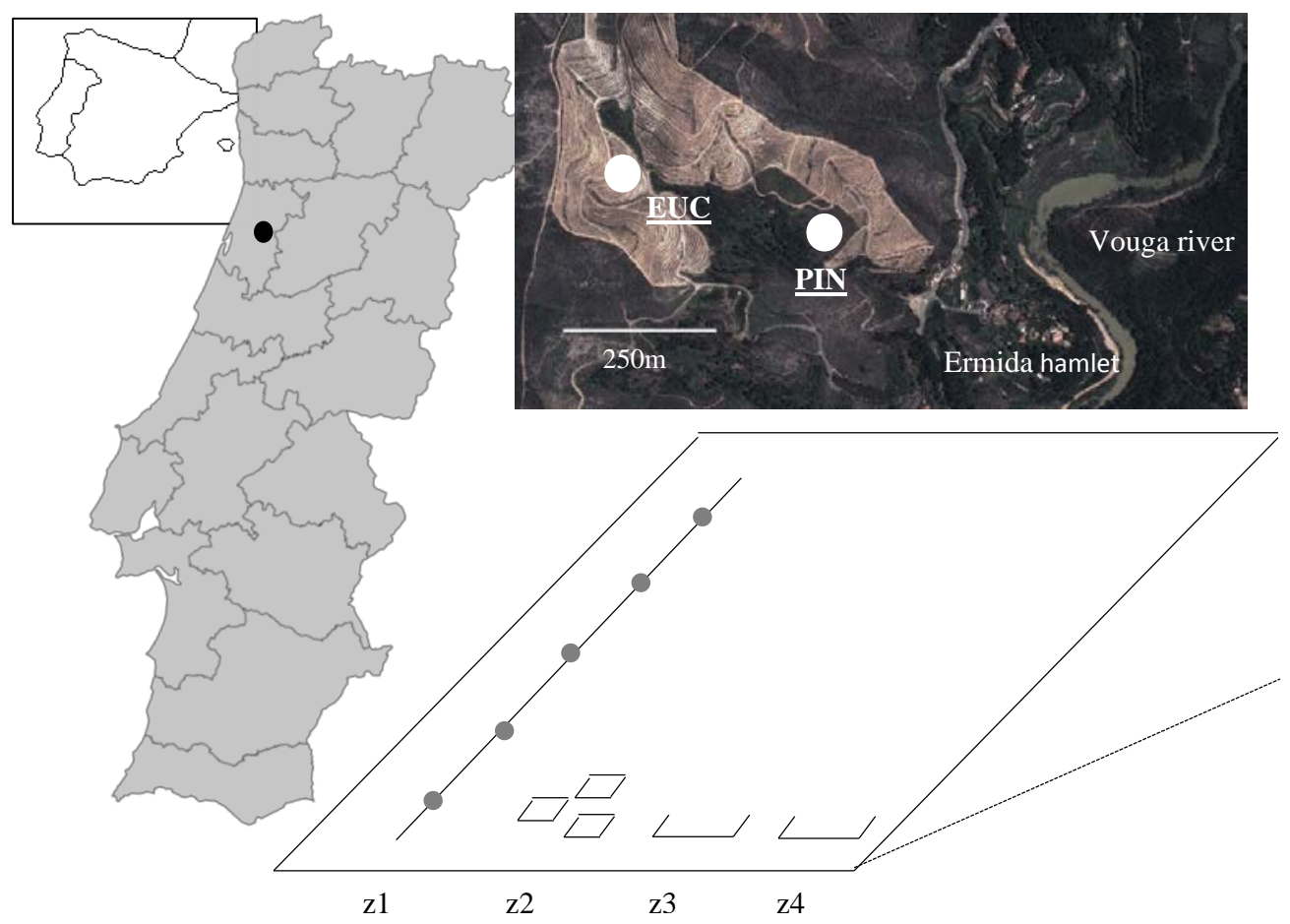

Fig. 2. Location of the study area and the two study sites, covered by an Eucalypt plantation ("EUC”) and a Maritime Pine plantation ("PIN"), and schematic representation of the experimental set-up, dividing a study slope in the following four strips: $\mathrm{z} 1=$ transects for destructive sampling; z2 = micro-scale runoff plots; z3 = slope-scale runoff plot; z4 = slope-scale erosion plot (sediment fence). 
In the winter of 2010, the two study sites were logged (and the trees removed) and then terraced with a bulldozer (March 2011). The Maritime Pine site was only partially terraced, in compliance with a reforestation plan approved prior the wildfire. In the authors' experience, this partially-terraced site represented a rather unique opportunity to study the effect of terracing through a direct comparison of two adjacent slope sections with presumably the same environmental settings and the same land-use/cover history.

\section{Experimental design}

Immediately after the wildfire, both study sites were divided into four strips running from the bottom to the top of the slope (Fig. 2). One of these strips (“z2" in Fig. 2) was selected for studying the hydrological and erosion response at the microplot scale, the topic of this study. At the base of this strip, 3 replicate micro-plots of approximately $0.25 \mathrm{~m}^{2}$ were installed at distances of $2-3 \mathrm{~m}$. The plot outlets were connected to one or more tanks of 30 or $70 \mathrm{~L}$ to collect the overland flow. This initial installation of the plots was completed by August 25, 2010, before the occurrence of any significant rainfall, as recorded by the various rainfall gauges installed within the burnt area and within a 1-km radius of the study sites.

During March 2011, the micro-plots at the Pine site were removed prior to the passage of the bulldozer, whereas the micro-plots at the Eucalypt site were left in situ to become shoved under by the bulldozer. Plot re-installation was done after terracing, and completed by March 23, 2011. By then, just a single weekly event with significant rainfall (total: $25 \mathrm{~mm}$; maximum intensity in $30 \mathrm{~min}: 7.5 \mathrm{~mm} \mathrm{~h}^{-1}$ ) had been missed, also because March 2011 was a dry month. At the Eucalypt site, three new micro-plots were installed at less than $10 \mathrm{~m}$ distance from the original plot location but they were placed on a trail rather than on the nearest terrace, to keep slope angle as similar as possible as that of the original plots (22-27 vs. $16-$ $\left.28^{\circ}\right)$. The same was done at the Pine site $\left(24-29^{\circ}\right.$ vs. $\left.15-32^{\circ}\right)$; in addition, however, three replicate plots were installed at the base of an adjacent section of the Pine slope that was not terraced.

\section{Field data and sample collection, laboratory and data analysis}

From August 25, 2010 till September 26, 2012, the runoff collected in the various tanks was measured at 1- to 2-weekly intervals, mainly depending on the occurrence of rainfall, at a total of 66 occasions (referred to as "events"). Whenever there was more than $250 \mathrm{ml}$ of runoff in a tank, a sample was collected (in a $1.5 \mathrm{l}$ bottle) and transported to the laboratory for analysis. The sediment concentration of these samples was then determined by filtration, using a paper filter with a pore diameter of $12-14 \mu \mathrm{m}$, followed by drying at $105^{\circ} \mathrm{C}$ during $24 \mathrm{~h}$ (APHA, 1998). The runoff and erosion figures of the replicate plots tended to suggest strongly asymmetrical distributions, so that median values were preferred over average values to present site-wise figures.

The 1- to 2-weekly field trips also involved measurement of the rainfall accumulated in four storage gauges (in-house design) that had been installed across the study area by the middle of August 2010. Their main purpose, however, was to validate the automatic recordings of four tipping-bucket rainfall gauges (Pronamic Professional Rain Gauge with $0.2 \mathrm{~mm}$ resolution) that had been installed at close proximity to the storage gauges.
The ground cover of the individual plots was determined at regular intervals during the study period, recognizing the following five cover categories: bare soil, stones (including rock outcrop), ashes (including charred plant materials), litter and vegetation. To this end, a square grid of $0.5 \mathrm{~m} \times 0.5 \mathrm{~m}$ was laid over the plots, and the cover category was recorded at 100 points where the grid's 10 equidistant rows intersected with its 10 equidistant columns. The ground cover data included in this study were those collected in January and May 2011, representing pre- and post-terracing conditions, respectively.

Resistance of the topsoil to shear stress was measured as an indicator of soil erodibility. This was done at several occasions during the study period, three of which are included in the present analysis (pre-terracing: November 2010; post-terracing: March and May 2011). At subsequent sampling occasions, transects were laid out at shifting positions across one of the fours strips in which the study slopes had been divided (" $\mathrm{z} 1$ " in Fig. 2). Along each transect, five equidistant points were selected where resistance to shear stress was measured at three spots per point, using a torvane. Since the distributions of the shear stress values seemed asymmetrical, median values were preferred over average values to present site-wise figures.

\section{RESULTS AND DISCUSSION Rainfall}

The first study year following the wildfire was close to a regular rainfall year, with $10 \%$ less rain than the long-term annual average at the nearest rainfall station (September 1, 2010 - August 31, 2011: 1,435 mm). The second year, however, was clearly a dry year, with less $25 \%$ rain than on average (September 1, 2011 - August 31, 2012: 1,207 mm). As a result, total rainfall was remarkably similar for the first, "preterracing” phase and the second, "post-terracing” phase of this study, especially taking into account their marked difference in duration (7 vs. 18 months). 1,205 mm of rainfall was recorded from the wildfire till March 9, 2011 as opposed to 1,412 mm from March 23, 2011 till September 26, 2012. The first and second study phases were also quite comparable in terms of the number of events with extreme rainfall amounts and intensities. The first study phase comprised three events with more than $100 \mathrm{~mm}$ in total and seven events with maximum 30-min intensities of more than $17.5 \mathrm{~mm} \mathrm{~h}^{-1}$, whereas the second phase comprised four and seven of such events, respectively.

\section{Overland flow at the Maritime Pine site}

At the Maritime Pine site, the non-terraced plots revealed a slightly lower median runoff coefficient during the first 7 months after the wildfire (28\%) than during the subsequent 18 months after the terrace construction (33\%) (Fig. 3). A difference of this order of magnitude could easily be attributed to spatial heterogeneity in hydrological behavior, since the runoff coefficients of the three replicate plots varied at least a factor 2 for both study phases (phase 1: 15 to $32 \%$; phase 2: 11 to $43 \%$ ). Possibly, however, this minor increase in runoff response with time-since-fire could reflect the observed disappearance of the ash layer and its substitution by bare soil (Fig. 4). Varies studies (e.g. Bodí et al., 2011; Larsen et al., 2009; Leighton-Boyce et al., 2007) have demonstrated that the presence of ashes can decrease overland flow generation.

The median runoff coefficient over the first study phase agreed reasonably well with the average figure of $22 \%$ reported by Prats et al. (2012) for a nearby Maritime Pine stand on schist 
over the first 2-3 months after a wildfire in 2007, in spite plot size was considerable larger $\left(16 \mathrm{~m}^{2}\right)$. Unlike in this study, however, the average runoff coefficient of the untreated plots in Prats et al. (2012) dropped considerably over the subsequent 10 months, to $10 \%$. In another Maritime Pine stand on schist, in central Portugal, Prats et al. (2013a) found markedly higher average runoff coefficients for untreated plots of $0.25-0.50 \mathrm{~m}^{2}$ during both the first year (50-60\%) and the second year (47\%) following a wildfire. This contrast in overland flow between the present study and Prats et al. (2012), on the one hand, and, on the other, Prats et al. (2013a) could, at least in part, be explained by the higher fire severity in the latter study, as indicated by an almost complete combustion of the Pine tree crowns as opposed to their scorching in this study and Prats et al. (2012). Such a differential effect of fire severity could operate directly, especially through heating-induced changes in topsoil hydrological properties (e.g. Cerdà, 1998; Mataix-Solera and Guerrero, 2007; Shakesby, 2011). It could, however, also work indirectly, in particular through the ground cover provided by needle cast from scorched crowns (e.g. Cerdà and Doerr, 2008; Larsen et al., 2009; Shakesby et al., 1993). In the present study, as shown in Fig. 4, and in Prats et al. (2012), the average litter cover attained $50 \%$ or more within the first few weeks after the wildfire, while it was less than $10 \%$ in Prats et al. (2013a).

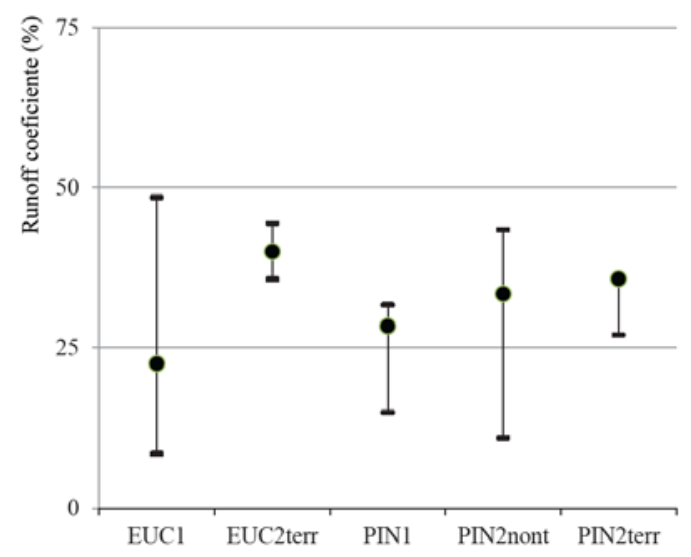

Fig. 3. Minimum, median and maximum runoff coefficients (\%) of the 3 replicate micro-plots at the eucalypt ("EUC") and Pine ("PIN") study sites over the first, pre-terracing (" 1 ”) and second, post-terracing (" 2 ") study phases, with the non-terraced/terraced plots of the second study phase being indicated as "nont" and “terr”, respectively.

At the Maritime Pine site, terracing did not seem to markedly change the overall runoff response (Fig. 3). The median runoff coefficient over the post-terracing phase was only slightly higher for the terraced than non-terraced plots (36 vs. 33\%). However, terracing did seem to reduce the spatial variability in overland flow generation, as the runoff coefficients of the three replicate plots differed clearly less at the terraced than undisturbed slope section (27-36\% vs. 11-43\%). This homogenizing effect of relocating large soil masses with a bulldozer was hardly surprising but its marginal impacts on runoff volumes was unexpected, also because terracing eliminated an extensive litter and vegetation cover (about 80\%; Fig. 4). Possibly, the pre-terracing vegetation-litter cover and the stone cover substituting it after terracing played comparable roles in overland flow generation, suggesting that the post-fire runoff response at the Pine site was controlled by resistance to flow rather than by rainfall interception. Likewise, Prats et al. (2013b) pointed out that the poor effectiveness of mulching in reducing post-fire runoff reported by Shakesby et al. (1996) would agree with the prevalence of resistance to flow over rainfall interception as runoff controlling factors.

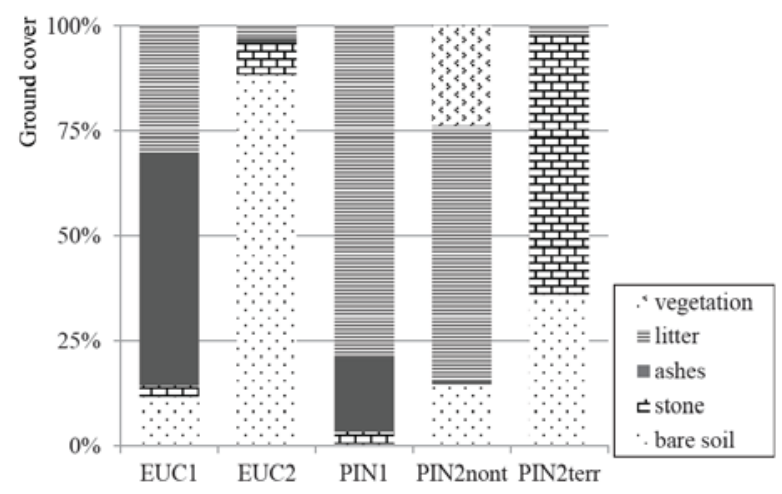

Fig. 4. Average ground cover of stones, bare soil, ashes, litter and vegetation of the 3 replicate micro-plots at the eucalypt ("EUC") and Pine ("PIN") study sites during the first, pre-terracing (“1”) and second, post-terracing ("2") study phases, with the nonterraced/terraced plots of the second study phase being indicated as "nont" and "terr", respectively. The data shown concerned January 2011 (phase1) and May 2011 (phase 2).

\section{Overland flow at the Eucalypt site}

At the Eucalypt site, overland flow generation over the first study phase was comparable to that at the Maritime Pine site, with a median runoff coefficient amounting to $23 \%$ (vs. $28 \%$; Fig. 3). However, the spatial variability in this initial post-fire runoff response was even more pronounced at the Eucalypt site than at the Pine site, as the replicate plot values differed by a factor 6 (8-48\% vs. a factor 2: $15-32 \%)$.

The median runoff coefficient at the present Eucalypt site was of the same order of magnitude as the average runoff coefficient that Prats et al. (2012) observed in a nearby Eucalypt stand (30\%), both over the first 2-3 months after a 2007wildfire (all plots) and over the ensuing 10 months (untreated plots). In an Eucalypt stand within the same burnt area as studied here, however, a noticeably larger fraction of the rainfall became, on average, overland flow during the first post-fire year (October 10, 2010-September 7, 2011: 55\%; Prats et al., 2013b). The referred differences in post-fire runoff between recently burnt Eucalypt stands could involve an inter-play of factors. Parent material and associated soil properties (e.g. soil texture) could explain the difference between this study (granite) and Prats et al. (2013b: schist), whereas plot size (Ferreira et al., 2008) could explain the difference between the two studies by Prats et al. (2012: $16 \mathrm{~m}^{2} ; 2013 \mathrm{~b}: 0.25 \mathrm{~m}^{2}$ ). The combined effect of parent material and plot size could then justify the difference between this study and Prats et al. (2012).

At the Eucalypt site, overland flow generation after terracing was markedly higher than during the initial post-fire period (Fig. 3). The median runoff coefficient was almost twice as high after terracing than before it (40 vs. 23\%). This difference could be explained by the marked reduction in the combined ash and litter cover from $85 \%$ before terracing to $5 \%$ afterwards and the associated increase in bare soil cover from roughly 10 to $90 \%$ (Fig. 4), through decreased interception, diminished soil sealing and/or reduced resistance to flow (Bodí et al., 2011; Larsen et al., 2009; Leighton-Boyce et al., 2007; Prats et al., 2012). Simultaneously, spatial variability in overland flow 
generation among the terraced Eucalypt plots was clearly smaller than among the non-terraced Eucalypt plots, with runoff coefficients that differed a factor $1.2(36-44 \%)$ as opposed to a factor 6 (8-48\%). Terracing thus appeared to homogenize the runoff response at the Eucalypt site to a greater extent than at the Pine site, eliminating the contrast in pre-terracing spatial variability between the two study sites (Eucalypt: 8-48\% vs. Pine: $15-32 \%)$.

\section{Erosion at the Maritime Pine site}

The non-terraced plots at the Maritime Pine site lost, in median, noticeably less sediments during the initial 7 months following the fire than during the subsequent 18 months (18 vs. $90 \mathrm{~g} \mathrm{~m}^{-2}$ ). This discrepancy was to a large extent due to a marked difference in specific sediment losses per unit of overland flow, which, in median, amounted to 0.08 and $0.25 \mathrm{~g} \mathrm{~m}^{-2}$ $\mathrm{mm}^{-1}$ runoff, respectively (Fig. 5). A possible explanation was the higher bare soil cover of the non-terraced plots studied during the second than first study phase (in average, 15 vs. $0 \%$ ). For example, Neris et al. (2013) attributed fire severity-related differences in inter-rill erosion rates to the presence of a Pine needle cover, whilst Malvar et al. (2013) explained an increase in inter-rill erosion rate after logging to the removal of the litter cover, increasing the bare soil cover. Spatial variability in specific sediment losses was similarly pronounced during both study phases, with value ranges that even overlapped (0.050.20 vs. $0.16-0.58 \mathrm{~g} \mathrm{~m}^{-2} \mathrm{~mm}^{-1}$ runoff).

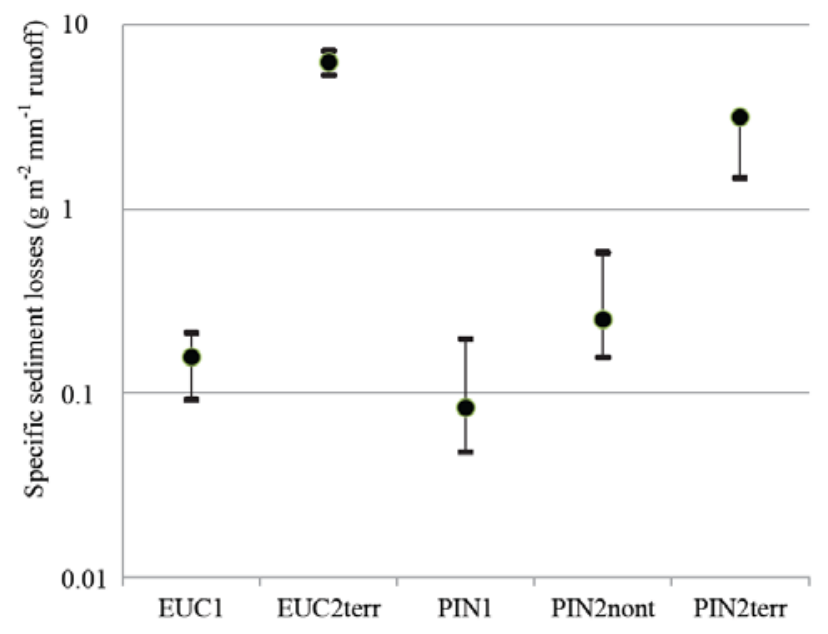

Fig. 5. Minimum, median and maximum specific sediment losses ( $\mathrm{g} \mathrm{m}^{-2} \mathrm{~mm}^{-1}$ runoff) of the 3 replicate micro-plots at the Eucalypt ("EUC") and Pine ("PIN") study sites over the first, pre-terracing ("1") and second, post-terracing ("2") study phases, with the nonterraced/terraced plots of the second study phase being indicated as "nont" and "terr", respectively.

The median specific sediment losses of this study were lower than the average values reported by Prats et al. (2012) for both their pre- and post-treatment period. The difference, however, was more striking for the initial 2-3 months following the wildfire (all plots: $0.51 \mathrm{~g} \mathrm{~m}^{-2} \mathrm{~mm}^{-1}$ runoff) than for the ensuing 10 months (untreated plots: $0.34 \mathrm{~g} \mathrm{~m}^{-2} \mathrm{~mm}^{-1}$ runoff). Clearly higher specific sediment losses were found by Prats et al. (2013a); they amounted, in median, to some $1.40 \mathrm{~g} \mathrm{~m}^{-2} \mathrm{~mm}^{-1}$ runoff during the first two post-fire years (untreated plots of $0.25-0.50 \mathrm{~m}^{2}$ ). This discrepancy could be explained by the higher fire severity in Prats et al. (2013a) than in this study and
Prats et al. (2012), and, in particular, by the associated, lower litter cover of mainly post-fire needle cast (see Fig. 4). The effectiveness of a Pine needle "carpet" to reduce post-fire erosion was suggested by Shakesby et al. (1993), and was later confirmed by Pannkuk and Robichaud (2003), Cerdà and Doerr (2008) and Neris et al., (2013) through laboratory and field rainfall simulation experiments. Besides fire severity, also postfire logging (Fernández et al., 2007; Malvar et al., 2013) could contribute to the comparatively high specific sediment losses in Prats (2013a).

At the Maritime Pine site, terracing seemed to have a striking impact on sediment losses (Fig. 5), in spite it did not on overland flow. The median sediment losses over the second study phase were more than an order of magnitude higher for the terraced than non-terraced plots (1213 vs. $90 \mathrm{~g} \mathrm{~m}^{-2}$ ). This discrepancy was by and large due to differences in specific sediment losses (3.18 vs. $0.25 \mathrm{~g} \mathrm{~m}^{-2} \mathrm{~mm}^{-1}$ runoff), as differences in median runoff amounted to less than $10 \%$. Terracing furthermore seemed to reduce spatial variability in specific sediment losses, at least in relative terms. In the case of the terraced plots, the values roughly differed a factor 2 (1.48-3.19 $\mathrm{g} \mathrm{m}^{-2} \mathrm{~mm}^{-1}$ runoff) as opposed to a factor 4 in the case of the non-terraced plots $\left(0.16-0.58 \mathrm{~g} \mathrm{~m}^{-2} \mathrm{~mm}^{-1}\right.$ runoff). Specific sediment losses were thus also consistently higher at the terraced than undisturbed slope section. The observed difference in specific sediment losses between the terraced and nonterraced section of the Pine slope agreed well with their difference in soil erodibility, as indicated by resistance to shear stress (in median, 1.3 vs. $2.5 \mathrm{~kg} \mathrm{~cm}^{-2}$; Fig. 6). The same applied, mutatis mutandis, to the spatial variability in specific sediment losses, with resistance to shear stress ranging from 0.5 to $2.0 \mathrm{~kg}$ $\mathrm{cm}^{-2}$ at the terraced slope part and from 1.0 to $3.5 \mathrm{~kg} \mathrm{~cm}^{-2}$ at the undisturbed slope part. Malvar et al. (2013) likewise found that specific inter-rill erosion rates following wildfire were significantly associated with resistance to shear stress, in spite they only studied sites that had been ploughed/terraced several years before the fire. By contrast, Neris et al. (2013) did not find that soil stability played a clear role in inter-rill erosion rates, when comparing light and moderate fire severities.

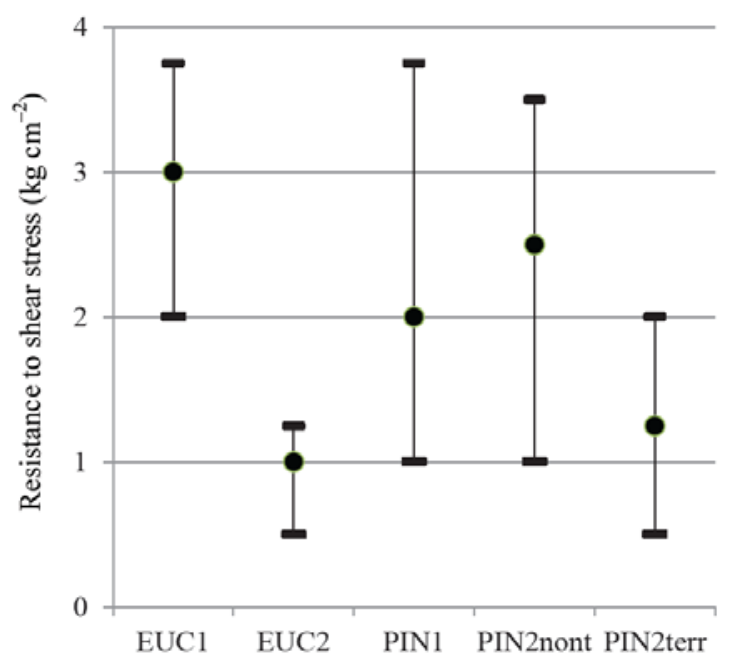

Fig. 6. Minimum, median and maximum resistance to shear stress $\left(\mathrm{kg} \mathrm{cm}^{-2}\right.$ ) at the Eucalypt ("EUC") and Pine ("PIN") study sites over the first, pre-terracing (" 1 ”) and second, post-terracing ("2") study phases, with the non-terraced/terraced plots of the second study phase being indicated as "nont" and "terr", respectively. The data shown concerned November 2010 (phase 1) and March-May 2011 (phase 2). 


\section{Erosion at the Eucalypt site}

At the Eucalypt site, sediment losses over the initial 7-month period were somewhat higher than at the Maritime Pine site, amounting to a median value of 25 as opposed to $18 \mathrm{~g} \mathrm{~m}^{-2}$. This difference was due to markedly higher specific sediment losses at the Eucalypt than Pine site (in median, 0.16 vs. $0.08 \mathrm{~g} \mathrm{~m}^{-2}$ $\mathrm{mm}^{-1}$ runoff; Fig. 5), which thus "compensated" the roughly $20 \%$ lower runoff at the Eucalypt site. The ranges in specific sediment losses, however, strongly overlapped for the two sites (0.09-0.21 vs. $0.05-0.20 \mathrm{~g} \mathrm{~m}^{-2} \mathrm{~mm}^{-1}$ runoff), so that no clear difference existed between the Eucalypt and Pine site in terms of spatial variability in initial post-fire erosion response.

The initial specific sediment losses at the Eucalypt site studied here were clearly lower than those at the nearby Eucalypt stand studied by Prats et al. (2012). Prats et al. (2012: all plots) reported an average value over the first 2-3 months that was three times higher than the present median value $\left(0.51 \mathrm{~g} \mathrm{~m}^{-2}\right.$ $\mathrm{mm}^{-1}$ runoff). Worth noting was that average specific sediment losses in Prats et al. (2012) became markedly higher during the subsequent 10 months (control plots: $1.16 \mathrm{~g} \mathrm{~m}^{-2} \mathrm{~mm}^{-1}$ runoff), which the authors largely attributed to the occurrence of two extreme rainfall events in spring. Even higher specific sediment losses were observed in a Eucalypt stand in the present burnt area studied by Prats et al. (2013b), averaging $2.69 \mathrm{~g} \mathrm{~m}^{-2} \mathrm{~mm}^{-1}$ runoff over the first post-fire year. The lower specific sediment losses in this study compared with Prats et al. (2012, 2013b) could reflect different parent materials, with granite giving rise to coarser soils than schist (as also observed here).

At the Eucalypt site, sediment losses were hugely different after than before terracing (Fig. 5). Median sediment losses were more than two orders of magnitude higher after terracing than before it ( 3.663 vs. $25 \mathrm{~g} \mathrm{~m}^{-2}$ ). This discrepancy mainly reflected differences in specific sediment concentrations, even though differences in runoff contributed in a significant manner too. The specific sediment concentrations were, in median, around 35 times higher for the second than first study phase (5.89 vs. $0.16 \mathrm{~g} \mathrm{~m}^{-2} \mathrm{~mm}^{-1}$ runoff). This contrast could involve the combined effect of differences in ground cover and differences in soil erodibility. The average bare soil cover increased from roughly 10 to $90 \%$ from before to after terracing (Fig. 4), whilst the median resistance to shear stress dropped from 3.0 to $1.0 \mathrm{~kg} \mathrm{~cm}^{-2}$ (Fig. 6).

The 35-fold difference in specific sediment losses between the post- and pre-terracing phase at the Eucalypt site closely approximated the corresponding difference at the Pine site (3.18 vs. $0.08 \mathrm{~g} \mathrm{~m}^{-2} \mathrm{~mm}^{-1}$ runoff). Nonetheless, the terraced Eucalypt plots lost, in median, about three times more sediments than the terraced Pine plots. This could be due to the markedly higher stone cover of the terraced Pine plots than of the terraced Eucalypt plots (on average, 8 vs. 63\%; Fig. 4), providing a protective stone lag against rain splash and/or runoff detachment (Shakesby, 2011; Terry, 1996). Spatial variability in sediment losses was of comparable magnitude in the case of the terraced Eucalypt plots as in the case of the terraced Pine plots $\left(3,356-5,256\right.$ vs. $\left.755-1,607 \mathrm{~g} \mathrm{~m}^{-2}\right)$. At the Eucalypt site, however, there was no clear suggestion that terracing reduced spatial variability in erosion response. The specific sediment losses of the replicate plots at the Eucalypt site varied to similar extents after than before terracing, at least in relative terms (5.35-7.27 vs. 0.09 to $0.21 \mathrm{~g} \mathrm{~m}^{-2} \mathrm{~mm}^{-1}$ runoff).

\section{Overall erosion assessment}

The present data provided a straightforward estimate of annual erosion rates for the Maritime Pine plantation and, in particular, for the slope part that was not terraced. Over the first two years following the wildfire, the non-terraced Maritime Pine plantation lost, in median, $0.5-0.6 \mathrm{Mg} \mathrm{ha}^{-1}$ year $^{-1}$ of sediments. A slightly higher figure $\left(0.7-0.8 \mathrm{Mg} \mathrm{ha}^{-1}\right.$ year $^{-1}$ ) could be inferred for the Eucalypt plantation, by assuming the same ratio of sediment losses during the first, pre-terracing study phase and during the second, post-terracing study phase as observed at the Pine site. The figures for both sites studied here were clearly below the median erosion rate of $2 \mathrm{Mg} \mathrm{ha}^{-1} \mathrm{y}^{-1}$ at which Shakesby (2011) arrived by reviewing plot-scale studies after moderate severity fires in the Mediterranean. Even so, more than half of these plot studies reported post-fire erosion rates below $1 \mathrm{Mg} \mathrm{ha}^{-1} \mathrm{y}^{-1}$, which Verheijen et al. (2009, 2012) proposed as threshold for tolerable soil loss. Nonetheless, other plot studies in recently burnt Maritime Pine and Eucalypt plantations in the present study region of central Portugal found markedly higher erosion rates. From these studies, Prats et al. (2013a) and Prats et al. (2013b) utilized plots of similar dimensions $\left(0.5-1 \mathrm{~m}^{2}\right)$ as the present study. The authors observed average sediment losses of 3-4 Mg ha ${ }^{-1} \mathrm{y}^{-1}$ during the first two post-fire years in a Pine plantation (Prats et al., 2013a), and 8-9 $\mathrm{Mg} \mathrm{ha}^{-1} \mathrm{y}^{-1}$ during the first post-fire year in a Eucalypt plantation (Prats et al., 2013b). Shakesby et al. (1996) and Prats et al. (2012) (like the bulk of the plot studies reviewed by Shakesby (2011) employed larger plots and found somewhat lower figures, amounting to 5-6 $\mathrm{Mg} \mathrm{ha}^{-1} \mathrm{y}^{-1}$ for plantations burnt one to two year earlier (Prats et al., 2012). The differences in post-fire erosion rates between the present and cited plot studies are not easily untangled but they clearly demonstrate that post-fire erosion can constitute a serious threat for sustainable forestry in wet Mediterranean regions as studied here.

Arguably, however, post-fire forestry operations are no less of a threat to land-use sustainability than especially lowseverity wildfires. This includes certain tree-logging practices (Fernández et al., 2004, 2007; Malvar et al., 2013) as well as rip-ploughing in downslope direction (Shakesby et al., 2002; Terry, 1996). The sediment losses following terracing observed in this study were clearly less than the $37 \mathrm{Mg} \mathrm{ha}^{-1} \mathrm{y}^{-1}$ following downslope rip-ploughing reported by Shakesby et al. (2002) but they did amount to $24 \mathrm{Mg} \mathrm{ha}^{-1} \mathrm{y}^{-1}$ in the case of the Eucalypt site. Post-terracing losses were three times less at the Pine site (8 $\mathrm{Mg} \mathrm{ha}^{-1} \mathrm{y}^{-1}$ ) than at the Eucalypt site, but terracing did produce a more than 10 -fold increase in sediment losses at the Pine site, when compared with the adjacent non-terraced slope section.

It is perhaps worth stressing that the post-terracing runoff and erosion rates reported here cannot be scaled-up directly, as they concerned trails and, thus, only a relatively minor part of the terraced area. Nonetheless, they did demonstrate in an unequivocal manner that the studied trails were subject to intense erosion processes, with due implications for their own maintenance and for that of other, connected parts of the study site's extensive trail network. The trail at the Eucalypt site did, in fact, also show extensive rill formation.

\section{CONCLUSIONS}

The principal conclusions of this study into the generation of overland flow at the micro-plot scale and the associated sediment detachment following a moderate-severity wildfire and terracing in two contrasting commercial tree plantations in 
north-central Portugal were the following: (i) runoff coefficients during the first 7 months following the wildfire were similar for the Pine and the Eucalypt plantation, in spite of the differences in tree species as well as parent material; they further agreed well with the results from prior plot studies in the study region; (ii) observed/inferred annual erosion rates over the first two years following the wildfire were also comparable at the two study sites; they were clearly below the figures reported by other post-fire erosion studies in the study region that employed micro-plots but agreed well with the majority of plot studies in the Mediterranean following moderate severity fire; (iii) terracing seemed to enhance overland flow generation and, at the same time, reduce its spatial variability at both study sites, but the impact on runoff volumes was more pronounced at the Eucalypt than the Pine plantation; (iv) terracing appeared to increase erosion rates at both study sites to a striking extent, by at least one order of magnitude; nonetheless the terraced Eucalypt plots produced three times more sediments than the terraced Pine plots.

Acknowledgements. The present study was carried out in the framework of the FIRECNUTS project (PTDC/AGRCFL/104559/2008), funded by the FCT/MCTES (PIDDAC), with co-funding by FEDER through COMPETE (Programa Operacional Factores de Competitividade; POFC), and with support of the research grants, attributed by FCT/MCTES, of SPA (SFRH/BD/ 33392/2008), SRF (SFRH/BD/75562/2010) and METV (SFRH/BPD/63808/ 2009). We further gratefully acknowledge the help of Margarida Caria, Raquel Ferreira, Ana Heitor, Stefan Van den Heuvel, Maruxa Malvar, Robbert de Lenne, Ton van der Linden, Max Shu Fen Sheng, Iryna Skulska, Hein Vermin and Jovana Vilimonovic with field data and sample collection and/or with laboratory analysis of the runoff samples. Finally, we are much obliged to the two anonymous reviewers for their contribution in improving the original manuscript.

\section{REFERENCES}

AFN - Autoridade Florestal Nacional. Estatística, 2012. Dados sobre incêndios florestais. (http://www.afn.minagricultura.pt/portal/dudf/estatisticas2012, accessed December 2012).

APHA - American Public Health Association, 1998. Total suspended solids dried at 105 degrees Celsius method 2540D. In: Standard Methods for the Examination of Water and Waste Water, $20^{\text {th }}$ ed., Washington, DC, USA.

Bodí, M.B., Mataix-Solera, J., Doerr, S.D., Cerdà, A., 2011. The wettability of ash from burned vegetation and its relationship to Mediterranean plant species type, burn severity and total organic carbon content. Geoderma, 160, 599-607.

Cardoso, J.C., Bessa, M.T., Marado, M.B., 1971. Carta dos solos de Portugal $(1: 1,000,000)$. Serviço de Reconhecimento e de Ordenamento Agrário, Secretaria de Estado da Agricultura, Lisbon, Portugal.

Cardoso, J.C., Bessa, M.T., Marado, M.B., 1973. Carta dos solos de Portugal (1 : 1,000,000). Agronomia Lusitana, 33, 461-602.

Cerdà, A., 1998. Changes in overland flow and infiltration after a rangeland fire in a Mediterranean shrubland. Hydrological Processes, 12, 1031-1042.

Cerdà, A., Bodí, M.D., 2007. In: Mataix-Solera, J. (ed.): Incendios forestales, suelos y erosión hídrica, 71-118. CEMACAM Font Roja-Alcoi.
Cerdà, A., Doerr, S.H., 2008. The effect of ash and needle cover on surface runoff and erosion in the immediate postfire period. Catena, 74, 256-263.

Cerdà, A., Giménez-Morera, A., Bodí, M.B., 2009. Soil and water losses from new citrus orchards growing on sloped soils in the western Mediterranean basin. Earth Surface Processes and Landforms, 34, 1822-1830.

DRA-Centro - Direcção Regional do Ambiente do Centro, 1998. Plano de bacia hidrográfica do Rio Vouga, $1^{a}$ fase, Análise e diagnóstico da situação de referência, Análise biofísica, Anexos. Lisboa, Portugal.

Ferreira, A. de Brum, 1978. Planaltos e montanhas do Norte da Beira - estudo de geomorfologia. Centro de Estudos Geográficos, Lisbon, Portugal.

Ferreira, A.J.D., Coelho, C.O.A., Ritsema, C.J., Boulet, A.K., Keizer, J.J., 2008. Soil and water degradation processes in burned areas: lessons learned from a nested approach. Catena, 74, 273-285.

Fernández, C., Vega, J.A., Fonturbel, T., Pérez-Gorostiaga, P., Jiménez, E., Madrigal, J., 2007. Effects of wildfire, salvage logging and slash treatments on soil degradation. Land Degradation and Development, 18, 591-607.

Fernández, C., Vega, J.A., Gras, J.M., Fonturbel, T., Cuiñas, P., Dambrine, E., Alonso, M., 2004. Soil erosion after Eucalyptus globulus clearcutting: differences between logging slash disposal treatments. Forest Ecology and Management, 195, 85-95.

Fernandéz-Raga, M., Fraile, R., Keizer, J.J., Varela, M.E.T., Castro, A., Palencia, C., Calvo, A.I., Koenders, J., Marques, R.L.C., 2010. The kinetic energy of rain measured with an optical disdrometer: An application to splash erosion. Atmospheric Research, 96, 210-240.

Keeley, J.E., 2009. Fire intensity, fire severity and burn severity: A brief review and suggested usage. International Journal of Wildland Fire, 18, 1, 116-126.

Larsen, I.J., MacDonald, L.H., Brown, E., Rough, D., Welsh, M.J., Pietraszek, J.H., Libohova, Z., Benavides-Solorio, J.D., Schaffrath, K., 2009. Causes of post-fire runoff and erosion: Water repellency, cover, or soil sealing? Soil Science Society of America Journal, 73, 4, 1393-1407.

Leighton-Boyce, G., Doerr, S.H., Shakesby, R.A., Walsh, R.P.D., 2007. Quantifying the impact of soil water repellency on overland flow generation and erosion: a new approach using rainfall simulation and wetting agent on in situ soil. Hydrological Processes, 21, 2337-2345.

Malvar, M.C., Martins, M.A., Nunes, J.P., Robichaud, P.R., Keizer, J.J., 2013. Repeated rainfall simulation experiments to assess post-fire overland flow generation and interrill erosion in six eucalypt stands in north-central Portugal. Catena, 108, 69-83.

Malvar M.C., Prats S.A., Nunes J.P., Keizer J.J., 2011. Post-fire overland flow generation and inter-rill erosion under simulated rainfall in two eucalypt stands in north-central Portugal. Environmental Research, 111, 222-236.

Mataix-Solera, J., Guerrero, C., 2007. Efectos de los incesios forestales en las propriedades edáficas. In: Mataix-Solera, J. (ed.): Incendios forestales, suelos y erosión hídrica, pp. 540. CEMACAM Font Roja-Alcoi.

Mataix-Solera, J., Cerdà, A., Arcenegui, V., Jordán, A., Zavala, L.M., 2011. Fire effects on soil aggregation: a review. EarthScience Reviews, 109, 44-60.

Moreira, F., Rego, F., Ferreira, P., 2001. Temporal (19581995) pattern of change in a cultural landscape of northwestern Portugal: implications for fire occurrence. Landscape Ecology, 16, 557-567. 
Neris, J., Tejedor, M., Fuentes, J., Jiménez, C., 2013. Infiltration, runoff and soil loss in Andisols affected by forest fire (Canary Islands, Spain). Hydrological Processes, 27, 19, 2814-2824.

Pannkuk, C.D., Robichaud, P.R., 2003. Effectiveness of needle cast at reducing erosion after forest fires. Water Resources Research, 39, 1333.

Pereira, J.M.C., Carreiras, J.M.B., Silva, J.M.N., Vasconcelos, M.J., 2006. Alguns conceitos básicos sobre os fogos rurais em Portugal. In: Pereira, J.S., Pereira, J.M.C., Rego, F.C., Silva, J.M.N., Silva, T.P. (Eds.). Incêndios Florestais em Portugal: Caracterização, Impactes e Prevenção, 133-161. ISAPress, Lisboa.

Prats S.A., MacDonald L.H., Monteiro M., Ferreira A.J.D., Coelho C.O.A., Keizer J.J., 2012. Effectiveness of forest residue mulching in reducing post-fire runoff and erosion in a pine and a eucalypt plantation in north-central Portugal. Geoderma, 191, 115-125.

Prats, S.A., Malvar, M.C., Vieira, D.C.S., MacDonald, L., Keizer, J.J., 2013a. Effectiveness of hydromulching to reduce runoff and erosion in a recently burnt pine plantation in central Portugal. Land Degradation and Development, doi: 10.1002/ldr.2236

Prats, S.A., Martins, M.A.S., Malvar, M.C., Ben-Hur, M., Keizer, J.J., 2013b. Polyacrylamide application versus forest residue mulching for reducing post-fire runoff and soil erosion. Science of the Total Environment, doi: 10.1016/j.scitotenv.2013.08.066

Radich, M.C., Alves, A.A.M., 2000. Dois séculos da floresta em Portugal. CELPA (Eds.), Lisboa, Portugal.

Shakesby, R.A., 2011. Post-wildfire soil erosion in the Mediterranean: review and future research directions. Earth-Science Reviews, 105, 71-100.

Shakesby, R.A., Doerr, S.H., 2006. Wildfire as a hydrological and geomorphological agent. Earth-Science Reviews, 74, 269-307.

Shakesby, R.A., Boakes, D.J., Coelho, C.O.A., Gonçalves, A.J.B., Walsh, R.P.D., 1996. Limiting the soil degradational impacts of wildfire in pine and eucalyptus forests, Portugal: comparison of alternative post-fire management practices. Applied Geography, 16, 337-356.

Shakesby, R.A., Coelho, C.O.A., Ferreira, A.D., Terry, J.P., Walsh, R.P.D., 1993. Wildfire impacts on soil erosion and hydrology in wet Mediterranean forest, Portugal. International Journal of Wildland Fire, 3, 95-110.

Shakesby, R.A., Coelho, C.O.A., Ferreira, A.J.D., Terry, J.P., Walsh, R.P.D., 1994. Fire, post-burn land management practice and soil erosion response curves in eucalypt and pine forests, north-central Portugal. In: Sala, M., Rubio, J.L. (Eds.): Soil erosion and degradation as a consequence of forest fires, 111-132. Geoforma Ediciones, Logroñes.

Shakesby, R.A., Coelho, C.O.A., Ferreira, A.J.D., Walsh, R.P.D., 2002. Ground-level changes after wildfire and ploughing in eucalyptus and pine forests, Portugal: implications for soil microtopographical development and soil longevity. Land Degradation and Development, 13, 111-127.

SNIRH - Serviço Nacional de Informação dos Recursos Hídricos. 2011. On-line hydrometeorological data base (http://www.snirh.pt; accesses December 2011).

Terry, J.P., 1996. Erosion pavement formation and slope process interactions in commercial forest plantations, northern Portugal. Zeitschrift fuer Geomorphologie, 40, 97-115.

Verheijen, F.G.A., Jones, R.J.A., Rickson, R.J., Smith, C.J., 2009. Tolerable versus actual soil erosion rates in Europe. Earth-Science Reviews, 94, 23-38.

Verheijen, F.G.A., Jones, R.J.A., Rickson, R.J., Smith, C.J., Bastos, A.C., Nunes, J.P., Keizer J.J., 2012. Concise overview of European soil erosion in research and evaluation. Acta Agriculturae Scandinavica, Section B - Plant Soil Science Acta, 62, 185-190.

WRB, 2006. World reference base for soil resources 2006. World Soil Resources Reports, 103. FAO, Rome.

Received 18 August 2013 Accepted 3 October 2013 